\title{
My Year of Writing through Diasporic Melancholy
}

\author{
Shui-yin Sharon Yam
}

Shui-yin Sharon Yam is Associate Professor in Writing, Rhetoric, and Digital Studies and Faculty Affiliate in Gender and Women's Studies and the Center for Equality and Social Justice at the University of Kentucky. She is a diasporic Hongkonger, and the author of Inconvenient Strangers: Transnational Subjects and the Politics of Citizenship (Ohio State University Press, 2019). Her book was shortlisted for the Rhetoric Society of America Book Award for 2019. Sharon's research has been published in the Quarterly Journal of Speech, Rhetoric Society Quarterly, Women Studies in Communication, among others. Her public writing has appeared in Foreign Policy, Hong Kong Free Press, and Lausan.

ince June 2019, I have been watching from afar as Hong Kong protesters and activists have taken to the streets repeatedly - first to demand the withdrawal of an extradition law that would allow the Hong Kong Chief Executive to extradite anyone Beijing demanded to mainland China, and later, as protests intensified and police violence became more rampant, amnesty for all arrested protesters and an independent investigation into the police force. In August, I sat on the floor of the fixer-upper I had just purchased with my partner in Lexington, Kentucky, my eyes glued to the livestream on my phone: antiriot police were brutalizing protesters in the Tai Koo subway station, the neighborhood where I grew up. I saw, mediated through a screen, police beating unarmed protesters with their batons as the protestors fled down an escalator. I would later find out that the police had also fired pepper balls and tear gas in close range of the protesters inside the subway station. As I began to create a new home in the United States, the home where I grew up was crumbling.

The dissonance I felt then as a diasporic Hongkonger would only intensify over the next few months into 2020. Because of the 12-hour time difference between Hong Kong and Lexington, I woke up to live footage of protests and police brutality on my phone. I played these livestreams in the background as I got ready for the day, the coffee maker making noise alongside protesters singing the anthem "Glory to Hong Kong." On the computer screen in my university office, I watched student protesters in Hong Kong wrestled to the ground, beaten up, and arrested by police, just when I was about to go teach and face my own students. Diasporic melancholy was, I realized, the ambiguous loss and heartbreak we face when the transnational politics that inform our every fiber are, for our peers, merely news headlines to be scrolled through.

Throughout the next few months, police violence and governmental suppression of dissent heightened. As of November, 2019, $\underline{8 \%} \%$ of Hong Kong's population was affected by tear gas. A year after the movement, close to 10,000 have been arrested, many of them youths. Watching the movement unfold, I struggled with an immense

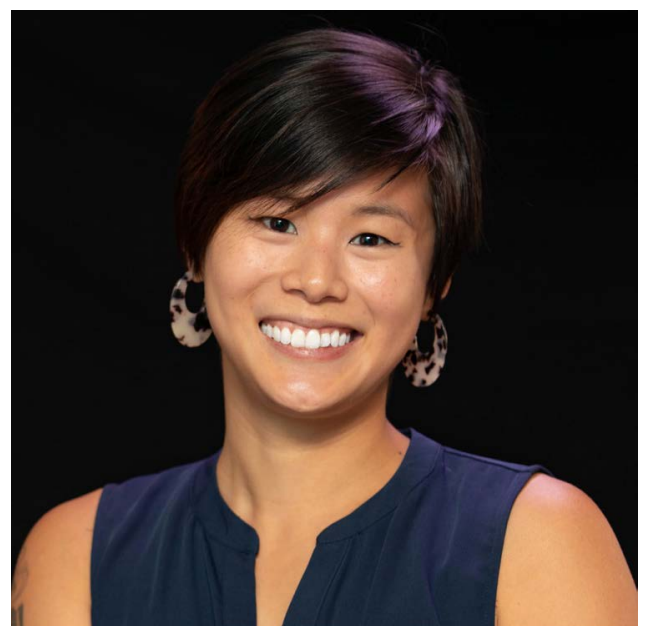

\begin{abstract}
In this personal narrative, I reflect on my changing relationship to writing as I used it to navigate the trauma, grief, and outrage I experienced as a diasporic Hongkonger in the US in 2019 and early 2020 . At the time, Hong Kong was embroiled in a massive pro-democracy movement against the government. I explore how my experience with writing shifts as I move from writing primarily for academic purposes to writing for a more public transnational audience. I also reflect on the complexity of navigating geopolitical tension while attempting to cultivate transnational cross-movement solidarity based on shared struggles against state violence.
\end{abstract}

\section{Keywords}

personal narrative, trauma, diaspora, hong kong, transnational, state violence 
sense of guilt for not being on the streets, for not putting my body at risk alongside fellow Hongkongers who were risking a ten-year sentence each time they went protesting. As an intersectional feminist and a researcher who studies social change and grassroots tactics, I understood that I was contributing to the movement by teaching and writing about Hong Kong and about the political structures that had led to the current turmoil. And yet, as I saw the campus of the Chinese University of Hong Kong engulfed in flame and protesters tackled and arrested en masse at the Polytechnic University of Hong Kong, it was hard to convince myself that writing a journal article about Hong Kong could in any way ameliorate the trauma, anger, and fear Hong Kong protesters and myself are experiencing.

I tried anyway. Having published numerous journal articles in rhetoric, I was comfortable and familiar with the genre. I began to consider how I could tap into my academic expertise to bring more attention to the movement in Hong Kong, specifically to amplify the experiences and tactics grassroots protesters were deploying. I feverishly finished a manuscript that used a reproductive justice framework to analyze the Hong Kong police's usage of tear gas. In it, I highlighted how activists from different backgrounds organized to combat this social and public-health crisis. For instance, medical professionals created an underground network that offered pro bono service to people who were injured; civilians with scientific training engaged in citizen science, collecting and analyzing samples from tear-gas cannisters since the police refused to release details of the gas's chemical content. I completed and submitted the manuscript in a week because of the sense of urgency I felt. I realized that the leisure to carefully ponder and pour over a manuscript for weeks, sometimes months, on end was a privilege not afforded to writers whose home was under siege, and hence my manuscript urgently demanded public attention. I had thought that by submitting the manuscript as swiftly as I could, I would be able to catch up with the speed with which collective trauma was accumulating. If I could catch up with the struggles Hong Kong protesters were facing, I thought at the time, I would feel less guilty. I was eager to do anything to alleviate the sense of powerlessness I felt bearing witness from afar. Writing had never felt more pressing to me. Trained to marinate my ideas and produce articles slowly for a largely academic audience, I was unaccustomed to writing under such exigence and heartbreak.

As the political turmoil in Hong Kong, and later the world, intensified, my relationship to and perception of writing and genres began to shift. The pandemic had first hit Hong Kong in February because of its proximity to mainland China, where the coronavirus outbreak originated. Hongkongers had, from the very beginning, adopted a universal mask policy. There was, however, a mask shortage that disproportionally affected poor people, disabled folks, and the elderly who could not wait in long lines to buy masks or could not afford the inflated prices. While people in the United States still saw COVID as a foreign disease that afflicted only those far away, I was spending most of my mornings and evenings talking to my anguished parents and grassroots organizations in Hong Kong that were collecting masks to donate to marginalized communities. As I combed through the Internet and local pharmacies in Lexington for surgical masks to ship to Hong Kong, I became enraged not only at the Hong Kong government's suppression of protest but also at their relative inaction to protect communities that were most impacted by COVID. Instead of turning to academic writing like I used to, on a whim I wrote an op-ed for the Hong Kong Free Press, an independent prodemocracy news platform founded as a response to the Umbrella Movement in 2014. Articulating how people who were most affected by the mask shortage were the ones who were already marginalized because of poverty, disability, and race, I illustrated in my op-ed why Hong Kong's mask shortage was a social justice issue. A few days later, my piece was published, and the editor of the press invited me to be a regular contributor.

As my op-ed circulated on the press's website and across social media platforms, it garnered support and positive reactions almost immediately from readers. Having spent weeks hunting for masks, many Hong Kong audiences found that my critique resonated with them. This was my first foray into public writing, and I did not expect the instant gratification and validation to feel as good as it did. Outside of conference presentations and private writing groups, in academia we rarely receive feedback so quickly from our readers and with so many deep, urgent emotions. Since then, I have been writing op-eds twice a month, using my training as a transnational rhetorician to weigh in on various sociopolitical issues in Hong Kong.

Writing as a diasporic scholar who has straddled traumatizing news and oppression across geopolitical contexts, I struggle with ideologies and ethical commitments that intersect and diverge in complex ways. In late 2019 , as protesters felt more desperate because they feared that their demands would not be met by the Hong Kong government, some began appealing to the United States explicitly - specifically, the Trump administration and GOP politicians like Marco Rubio, Ted Cruz, and Josh Hawley who had expressed support for the Hong Kong movement as a way to challenge Beijing. Most protesters in Hong Kong understood that Trump was most concerned with his own interests but chose to appeal to him anyway, since he was a strongman figure with a "tough on China" platform. A faction of protesters who harbored right-wing nativist values, however, genuinely supported Trump and had held up banners and signs that represented Trump as the hero. ${ }^{1}$ As a diasporic Hongkonger in the United States, I supported the movement's antiauthoritarian agenda, but I also vehemently opposed the Trump administration and the ideologies it stood for. In May,

\footnotetext{
1 Mainstream Hongkongers' support for Trump intensified during the 2020 US presidential election, which came after the implementation of the draconian National Security Law that criminalizes all protests and forecloses institutional outlets for dissent.
} 
as Trump continued to jeopardize the health and safety of the American public by mishandling the pandemic, I penned an op-ed urging Hongkongers to reconsider their thin alliance with Trump.

A few hours after it was published online, the Facebook comment section of the essay and my Twitter mentions were filled with venomous criticisms and ad hominem attacks. While I could stomach attacks from American Trump supporters, the comments from local Hong Kong people hurt the most. Based on the logic that one's enemy's enemy is one's friend, both groups had equated my criticism of Trump with unequivocal support for the Chinese Communist Party. Other Hongkongers criticized me for writing from the ivory tower as a diasporic person in the United States without a keen understanding of the despair and desperation on the ground.

While I understood that the Hongkongers who attacked me did not represent all activists in the movement and that there were left-wing protesters who shared my thoughts, I began to feel like an imposter, a traitor almost. Because the movement was decentralized with protesters from different camps enacting various tactics, the movement had developed an ethos of solidarity, one that demanded protesters and activists never criticize one another publicly. Scholars and critics have pointed out that this feature had concretized organizing tactics in a way that made the movement ideologically unadaptable. Having this knowledge, however, did not make those comments about me any less hurtful. Keenly aware of distance and position of privilege, I critically pondered whether I could stand behind my argument, and even if so, whether it was right for me to have written it so publicly.

Because I am a professor whose primary writing experience has been in the confines of academia, my writing rarely has the immediate emotional and political impact my op-ed writing has had on myself and my readers, including Hongkongers who are struggling against an increasingly authoritarian and repressive regime. As I continued to write publicly, I realized that donning the analytical hat of a rhetorician helped me more critically understand the negative feedback I received from readers on social media. That understanding, in turn, ameliorated the emotional pain. Rhetorical knowledge also provided me a way to more thoughtfully navigate difference in positionality and ideologies within my own community of Hongkongers. In my scholarship, I have considered the relationship between critical empathy and anthropologist Arlie Hochschild's theory of the "deep story": that our arguments are based primarily on the stories of realities we tell ourselves. Bearing in mind these rhetorical concepts and applications, instead of internalizing the critiques I received from local Hongkongers, I asked, "What motivated them to feel this way, and to believe in this ideology? Why would they choose to mobilize this particular example as evidence?" I was, to put it differently, practicing what Krista Ratcliffe calls "rhetorical listening" as I listened to and for the cultural logics that motivated Hongkongers' support for Trump.
The rhetorical ecology surrounding Hong Kong became more complicated as the geopolitical tension between Washington and Beijing escalated, with the two governments lambasting each other's human-rights violations while denying the state violence they inflicted on their own citizenry. Meanwhile, fanned by the Trump administration during the pandemic, anti-Chinese sentiment in the United States was also on the rise. Trump and the GOP's anti-China platform had motivated many of his supporters in the United States to support the Hong Kong movement as a means to attack the Chinese government. I was, hence, acutely aware that my writing about Hong Kong could be appropriated and redeployed by white supremacists.

Meanwhile, in Hong Kong, Beijing had bypassed Hong Kong's supposedly autonomous legislative structure to impose a set of national security laws, laws that would broadly incriminate anyone locally and abroad who engages in activities that challenge the regime. After this law was implemented on July 1, 2020, Hongkongers began to scrub their social media profiles and self-censor in fear that they would be prosecuted and potentially face a life sentence. On the one hand, because of the chilling effect the national security laws have on local Hongkongers, I now have an obligation to fill the void and speak up against Beijing's suppression. On the other hand, however, as many Americans conflate the Chinese Communist Party (CCP) with Chinese people writ large, my critiques of the CCP might be circulated in ways that intensify Sinophobia in the United States, resulting in violence inflicted on Asian Americans and immigrants like me. Indeed, since the relationship between the two states worsened, I noticed an uptick of Twitter followers on my account who were far-right Trump supporters in the United States. The binary logic reared its head once again: if we share the same "enemy," then I must be a friend of theirs. On the flip side, when I tweeted and wrote against racism towards Chinese people, I garnered support from pro-CCP Chinese nationalists who would later hurl insults at me for my critiques of Beijing's repressive policies in Hong Kong and Xinjiang. Transnational rhetoricians have reminded us that as discourse travels in interconnected networks of power across state boundaries, they are often repurposed and redeployed in ways that eclipse the rhetor's intent and the texts' originating context. My experience as a diasporic writer gave me an embodied understanding of what it means to do and analyze transnational rhetoric.

My academic expertise in transnational rhetoric became even more relevant to my public writing when I began advocating online for grassroots transnational solidarity between Hong Kong activists and the Black Lives Matter protests in the United States. Despite historical and contextual differences between the two movements, both groups of activists demand a radical overhaul of the current police system while uncovering how the state has been inflicting physical and emotional violence on those who dare challenge the existing systems of power. Further, the BLM protests provided a key moment for mainstream Hongkongers to confront and address the rampant racism and anti-Blackness in the city that often went 
unchecked. I penned an op-ed for a Hong Kong audience that highlighted the coalition potential between the two movements and conversed with local Hongkongers on social media platforms who were skeptical or outraged by this argument. While, like BLM protesters, Hong Kong activists have been brutalized by the police and have called for the abolishment of the police force, many local Hongkongers have chosen to denounce or remain silent about the BLM protests. Desperate to garner support from political actors they deemed powerful enough to oppose the Chinese government, local Hongkongers feared that their support for the BLM protests would offend Trump and Republican lawmakers who had been the most vocal supporters in Washington of the Hong Kong prodemocracy movement as part of their anti-China platform.

I was not alone in attempting to foster transnational grassroots solidarity between Hong Kong activists and the BLM movement in the United States. Hong Kong activists on the political left, including many diasporic Hongkongers, have argued repeatedly on digital spaces and in various publications that rather than appealing to the Trump administration and right-wing politicians for help, Hong Kong activists ought to engage in coalition building with other grassroots movements in ways that acknowledge rather than subsume difference.

These activists and thinkers, especially those who contribute to the Lausan Collective, a decolonial organizing and publication platform created mostly by diasporic Hongkongers, have modeled why we ought to cultivate transnational grassroots solidarity through writing and other forms of activism. For example, while Beijing used the United States' national security policies to justify its own national security laws in Hong Kong, the Duterte regime in the Philippines cited examples from Australia and announced a similarly draconian antiterrorism law. Meanwhile, Beijing was also responsible for sending thousands of rifles to the Philippines to help with its "counterterrorism" mission. In addition, as activists in the United States called for abolishment of the police, Trump's executive order on Hong Kong revealed that the Department of State has been responsible for training the Hong Kong police, now infamous for their brutality and lack of accountability. By publishing and translating articles written collaboratively with activists in Lebanon, the Philippines, Indonesia, and Thailand, and by hosting panel discussions that bring together local Hong Kong organizers and Black activists from the United States, Lausan organizers demonstrate how, in spite of geographical distance and contextual differences, our struggles are intimately linked transnationally.

As diasporic subjects who live at the intersection of sometimes competing cultural contexts and transnational geopolitics, we do not fit neatly into dominant lines of belonging. This positionality allows us to embody what Aimee Carillo Rowe calls "differential belonging" in Power Lines: On the Subject of Feminist Alliances: namely, it is a politics of relations that allows "cultural workers to move among and across these various positionalities and loyalties ... without feeling trapped or bound by any one in particular"
$(33,41)$. On Twitter, diasporic Hongkongers in the United States highlighted the strong sense of déjà vu and reignited trauma we felt when we saw video footage from Portland. In addition to similarities in protest tactics shared by activists on social media, the methods the police and government used to suppress the protesters were also similar. In both the United States and Hong Kong, protesters were beaten and dragged into unmarked vehicles by state agents who disguised their identity and badge number. In both cases, authoritarian state leaders had called for harsh militant suppression of protesters while denouncing them as "rioters."

For those of us who have participated in and borne witness to grassroots uprising across state boundaries, the collective trauma and coalition potential of this moment are often felt on a transnational scale, motivating us to articulate a praxis of transnational grassroots solidarity that decenters the state. In Political Emotions: Why Love Matters for Justice, Martha Nussbaum opines that emotions play a key role in whether and how we promote social justice causes that do not directly impact us. Nussbaum posits, "If distant people and abstract principles are to get a grip on our emotions . . . these emotions must somehow position them within our circle of concern, creating a sense of 'our' life in which these people. . . matter as parts of our "us"' (11). As a diasporic Hongkonger, I intimately felt the fear, rage, and grief that came with participating in a movement that has resulted in immense physical and emotional trauma, a movement that has been hampered by the implementation of a draconian national security law. While I will never occupy the same positionality as BLM activists in the United States, the women protesters in Belarus, or the student activists in Thailand, I recognize our shared struggles against an authoritarian state structure that renders lives unlivable for many, and I also understand, in an embodied way, what it is like to live and struggle under a constant state of rage, numbness, grief, and terror.

Carillo Rowe writes that with "coalitional subjectivity," the subject "sees her oppression and privilege as inextricably bound to others and when she cannot envision her existence and politics as separate from others' existence and politics" (10). Diasporic Hongkongers in the United States-including myself-understood that the same right-wing politicians who supported the HK movement were also the ones who advocated for military suppression of Black and brown protesters in the United States. As people of color and immigrants in the United States, we had experienced firsthand the trauma and violence inflicted by the Trump administration in ways that are reminiscent of the authoritarian regime Hongkongers are struggling against. Our concerned critiques of this realpolitik alliance with the American right are sometimes met with vitriolic pushback from local Hongkongers who believe that we are speaking solely from a position of privilege as diasporic subjects who are not in immediate danger of state violence and suppression, much like the pushback I received after writing my op-ed on Trump months ago. 
As I continued to engage in dialogues with Hongkongers from different positionalities and wrote alongside them, I realized that I was enacting deliberative empathy, a rhetorical concept I developed in my academic monograph Inconvenient Strangers: Transnational Subjects and the Politics of Citizenship. Deliberative empathy is an emotional response and practice that promotes coalitional thinking. It combines constitutive deliberative acts with the critical cognitive model of empathy, urging interlocutors to identify overlapping interests with others through shared material context. Rather than denouncing local Hongkongers who prioritize what they consider realpolitik over transnational grassroots solidarity, I understood that their perspective stemmed from a deep sense of dread and desperation because of how dire the situation is on the ground in Hong Kong. Under the National Security Law, the Hong Kong police has arrested and prosecuted activists, former lawmakers, and protesters for "seditious crimes" such as carrying a "Liberate Hong Kong" banner. Seen through this lens, they were not entirely wrong in calling out the relative safety and privilege we enjoy as diasporic activists who are implicated by Hong Kong's sweeping National Security Law, but do not face immediate arrests for challenging the Hong Kong government's draconian policies.

On the other hand, diasporic Hongkongers who work alongside Black and brown activists in the US understand intimately that state and police violence is a transnational phenomenon that is not limited to Hong Kong, and they have resisted the tendency to exceptionalize the conditions in Hong Kong. To this day, I continue to sit with and live by the question: How can we mobilize deliberative empathy in conjunction with diasporic sensibilities to cultivate transnational solidarity and coalition across grassroots movements while holding ourselves accountable to the interests of our different co-strugglers across contexts? How can we effectively articulate and critique interconnected systems of power that led to the violence marginalized people face transnationally, while accounting for specific political contexts and affective attachments?

Inspired by the writing and organizing work of Lausan and other Hong Kong-based transnational advocacy like the Borderless Movement, I started gathering data to write an academic article in rhetorical studies that examines the fraught rhetorical work involved in cultivating transnational coalitions. By analyzing how activists in the United States and Hong Kong navigate complex geopolitical tensions and cultural differences, I planned on using this as a case study to illustrate coalitional rhetoric in situ. I conducted research for this article while engaging in activism on social media. In the process, I discovered that a group of self-proclaimed far-left authoritarian regime apologists in the West (commonly called "tankies" or "alt-imperialists" on social media) had been spreading conspiracy theories and disinformation about the Hong Kong protest, claiming that the movement was orchestrated by the CIA and that the protesters were funded by the U.S. government. Since the BLM protests began, this group-led by writers and founders of the conspiracy news platform Grayzone-had been dissuading liberals in the United States who support BLM to denounce the Hong Kong movement. Citing state-sponsored media from Beijing and the faction of Hongkongers who appeal to Trump and the GOP, they posited that the Hong Kong movement was a far-right movement, contrary to the BLM uprising. As activists from both movements and diasporic Hong Kong public intellectuals have repeatedly pointed out, the two movements in fact share similar struggles against police violence and unchecked state power in criminalizing dissent. As a transnational rhetorician and diasporic Hongkonger, I understand acutely how the protest tactics and beliefs of local Hongkongers could be interpreted differently and misconstrued once entered into the U.S. rhetorical context.

As I researched the arguments and rhetorical artifacts of tankies, I stumbled across a website that espoused the pro-China, alt-imperialist ideology. I had been enjoying putting my rhetorician hat on to analyze the sometimes intersecting and sometimes contradicting arguments among different stakeholders, but my heart stopped when I saw my name and my writing on that website. Using mis- and disinformation, the unnamed author of the site had mercilessly mocked me and critiqued the op-ed I wrote on transnational solidarity. The journal manuscript I was working on suddenly took on unexpected emotional weight.

Later that week, as I continued to dialogue with other diasporic Hongkongers about this tension on Twitter while gathering primary artifacts for research, I was accidentally pulled into a controversy: youth-led advocacy groups in the Sunrise Movement had decided to cancel a webinar with leftist Hong Kong organizer Johnson Yeung after they were attacked vehemently by China apologists and pro-Beijing conspiracy theorists. In one window, I had a Word document opened for my manuscript draft, and in the other, I was explaining to a social media organizer from the Sunrise Movement why Hong Kong activists were incensed and saddened by their cancellation. A few hours later, I received an email inquiry from a journalist, inviting me to weigh in on this controversy for a news article. The article was published a few days later, and I was quoted extensively in it. As I cited this news article in my manuscript, I inadvertently turned my own words and experience into primary data. I became, simultaneously, the subject and object of my research.

This uncanniness is perhaps what defines the messiness and possibilities of writing from a transnational diasporic orientation. Since the wave of global uprising during the pandemic, I have come to realize that the transnational sensibility that emerges from witnessing shared political struggles and experiencing collective trauma orients us differently than do rigid lines of identification defined by nation-state boundaries or cultural and ethnic sameness. As a diasporic subject in the United States, especially one who comes from a former British colony and now a neocolony under Beijing, I have never fully belonged to a national community defined by fixed identities and allegiances defined by the state. In other words, the only way to write and to make sense of the world is by constantly 
interrogating how my subjectivity is connected through complex geopolitical networks not only to local Hongkongers but also to others who share similar material conditions and struggles. To write transnationally, then, is to hold in tension competing worldviews, messy lines of allegiances, and at this very moment, the collective trauma and shared rage, despair, and hope in creating a more humane political future.

\section{Works Cited}

Dingo, Rebecca, Rachel Riedner, and Jennifer Wingard. "Toward a Cogent Analysis of Power: Transnational Rhetorical Studies." JAC 33, no. 3/4 (2013): 517-28.

Hochschild, Arlie Russell. Strangers in Their Own Land: Anger and Mourning on the American Right. New York: The New Press, 2016.

Nussbaum, M. C. (2013). Political emotions. Harvard University Press.

Ratcliffe, Krista. Rhetorical Listening: Identification, Gender, Whiteness. Carbondale: Southern Illinois University Press, 2006.

Rowe, Aimee Carrillo. Power Lines: On the Subject of Feminist Alliances by Aimee Carrillo Rowe. Duke University Press Books, 2008.

Yam, Shui-yin Sharon. Inconvenient Strangers: Transnational Subjects and the Politics of Citizenship. 1st edition. Columbus: Ohio State University Press, 2019. 